Connotas. Revista de crítica y teoría literarias 
CONNOTAS. REVISTA DE CRÍTICA Y TEORÍA LITERARIAS. Enero - diciembre 2013, es una publicación anual editada por la Universidad de Sonora, a través de la División de Humanidades y Bellas Artes, en el Departamento de Letras y Lingüística. Blvd. Luis Encinas y Blvd. Rosales s/n, Col. Centro, C.P. 83000, Hermosillo Sonora; Tel. (662) 2592 136, (662) 2592 157, <www.uson.mx>, <http://www.connotas.uson.mx, connotas@capomo.uson.mx>. Editor responsable: Rosario Fortino Corral Rodríguez. Reservas de Derechos al Uso Exclusivo núm. 04-2006-020714184900-102. ISSN: 18706630; ambos otorgados por el Instituto Nacional del Derecho de Autor. Licitud de Título núm. 13434 y de Contenido núm. 11007, otorgados por la Comisión Calificadora de Publicaciones y Revistas Ilustradas de la Secretaría de Gobernación. Este libro se publicó con el apoyo del Programa Integral de Fortalecimiento Institucional C/PIFI 2013-12934

Se autoriza la reproducción total o parcial de los contenidos de la presente publicación, siempre y cuando se acredite adecuadamente el origen de los mismos.

Datos de contacto para la publicación: División de Humanidades y Bellas Artes, Departamento de Letras y Lingüística; Apartado Postal 793, Col. Centro, C.P. 83000, Hermosillo, Sonora, México. Tels.: (662) 259-21-87, Tel-fax 212-55-29. Correo electrónico: connotas@capomo.uson.mx Página web: http://www.connotas.uson.mx 


\section{Connotas. Revista de crítica y teoría literarias}

Núm. 13, año 2013

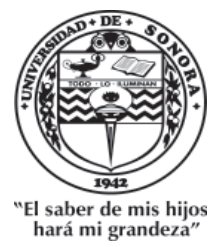


UNIVERSIDAD DE SONORA

RECTOR

Heriberto Grijalva Monteverde

VICERRECTORA

Arminda Guadalupe García de León Peñúñuri

Secretario General Académico

Enrique Fernando Velázquez Contreras

División de Humanidades y Bellas Artes

María Rita Plancarte Martínez

Departamento de Letras y LingÜística

Ana Bertha de la Vara Estrada

César Avilés Icedo

Rosa María Burrola Encinas

Fortino Corral Rodríguez

Leticia Martínez Figueroa

Jesús Abad Navarro Gálvez

Gabriel Osuna Osuna

María Rita Plancarte Martínez

DiRECTOR

Fortino Corral Rodríguez

Giuseppe Bellini

Consejo InTERnacional

Universidad de Milán

Carlos Pacheco

Luis Beltrán Almería

Universidad Simón Bolivar

Universidad de Zaragoza

Rafael Olea Franco

Helena Beristáin

El Colegio de México

Joan Oleza Simó

Universidad Nacional Autónoma de México

Universidad de Valencia

Raúl Bueno-Chávez

Dartmouth College

Julio Ortega

Evodio Escalante

Brown University

Luz Aurora Pimentel

Universidad Autónoma Metropolitana

Universidad Nacional Autónoma de México

Beatriz González-Stephan

Susana Reisz

Rice University

Aníbal González

The City University of New York.

José Carlos Rovira

Universidad de Alicante

Yale University

Aurelio González Pérez

Charles Tatum

El Colegio de México

Yvette Jiménez de Báez

The University of Arizona

Jorge Urrutia

El Colegio de México

Universidad Carlos III de Madrid

Nelson Osorio Tejeda

Universidad de Santiago de Chile

Emil Volek

Arizona State University 


\section{Índice}

\section{Artículos}

Una hermenéutica analógica para la literatura

Mauricio Beuchot Puente

La obra de Jorge Luis Borges durante la década de 1930: estudio de algunos elementos para la conformación de su poética en Discusión (1932)

Daniel Zavala Medina

Metáforas de la locura y la muerte en "Río subterráneo" de Inés Arredondo

Gabriel Osuna Osuna

La alteridad como vector de la construcción del yo: La muerte me da de Cristina Rivera Garza y El Gran Vidrio de Mario Bellatin Véronique Pitois Pallares

Uno soñaba que era rey de Enrique Serna: un espacio de contradicción Claudia Gidi

Una angustia compartida. Análisis de la voz narrativa en Mi hermano Carlos de Jorge López Páez

Jorge Antonio Muñoz Figueroa

De Los perros románticos y otros poemas de Roberto Bolaño Marina Martínez Andrade 
Las novelas del Crack, multiplicidad y superposición de mundos Ramón Alvarado Ruiz

La construcción del “otro" en la Relación de la jornada de Cíbola de Pedro Castañeda de Nájera

Guillermo Martínez Sotelo

Destino e historia en Margarita, está linda la mar de Sergio Ramírez

María Rita Plancarte Martínez

\section{Notas}

Identidad negada y mundo al revés en Santa María del Circo de David Toscana

César Avilés Icedo y María Elena González Borgaro 203

"El buen ejemplo" de Vicente Riva Palacio: la historia de un cuento

Marco Antonio Chavarín González

Organización descriptiva en Catarina de San Juan, princesa de la India y visionaria de Puebla

Silvia Guadalupe Alarcón Sánchez

Genealogías en Todo aqui es polvo de Esther Seligson. Lectura a partir de los epígrafes

Luz Elena Zamudio Rodríguez

\section{Reseñas}

Martha Elena Munguía Zatarain. La risa en la literatura mexicana (apuntes de poética)

Silvia Alicia Manzanilla Sosa 
Véronique Pitois-Pallares. El arte del fragmento: El Gran Vidrio de Mario Bellatin

Julio César Zárate Ramírez 255

Nicolás Kanellos. Hispanic Immigrant Literature: El sueño del retorno Josué Gutiérrez González

Dante Salgado. Brevísima relación de la idea de amor en Occidente Diana Vanessa Geraldo Camacho 271

Mara L. García. Paco Yunque: una mirada crítica Juan Paredes Carbonell 279

Abstracts 283

Résumés

Normas editoriales 



\title{
De Los perros románticos y otros poemas de Roberto Bolaño
}

\author{
Marina Martínez Andrade*
}

Resumen:

Roberto Bolaño no sólo fue narrador sino también poeta, un poeta notable que amaba su oficio, hecho que no debe soslayarse al intentar la valoración completa de su obra, pues sus poemas aparte de ser valiosos por sí mismos constituyen peldaños para llegar a su narrativa. Este artículo incursiona en su poemario Los perros románticos (1995) y en algunos poemas incluidos en su libro póstumo La Universidad Desconocida (2007), especialmente en aquellos en que el poeta hace un recuento de su vida y sumergido en la nostalgia evoca fragmentos de su juventud rebelde e iconoclasta en México junto a sus compañeros infrarrealistas. Aunque estos poemas se nutren de muchas maneras en el movimiento de juventud de Bolaño, su poesía aparece decantada a través del tiempo y su horizonte estético desborda el pasado anhelo de ruptura y subversión.

\section{Palabras clave:}

Infrarrealismo, subversión de lo cotidiano, registro autobiográfico, poetas-perros-detectives, autorretratos, nostalgia de México, lucidez-alucinación.

Después de la muerte del singular escritor chileno Roberto Bolaño, ocurrida en 2003, no cabe duda que estamos viviendo el "efecto

* Universidad Autónoma Metropolitana. Iztapalapa. 
Bolaño" en el campo literario hispanoamericano. Sus novelas y cuentos cada día ganan más lectores, al grado que ocupan actualmente los primeros lugares de ventas, se encuentran en constante traducción e internacionalización y son discutidos por la crítica; además, son objeto de estudio en varias tesis de posgrado que están en proceso o se han concluido y es vasta la difusión que su obra y figura alcanzan entre los internautas, a través de páginas web, notas biográficas, noticias, artículos y documentales. Pero Bolaño no sólo fue narrador sino también poeta, un poeta notable que amaba su oficio, hecho que muchas veces se desconoce y debe tenerse en cuenta al intentar la valoración completa de su obra, pues sus poemas, aparte de ser valiosos por sí mismos, constituyen peldaños para llegar a su narrativa.

Se centra mi trabajo en algunos poemas incluidos en Los perros románticos (1995) y otros en La Universidad Desconocida (2007), especialmente aquellos en que el poeta hace un recuento de su vida y sumergido en la nostalgia evoca fragmentos de su juventud rebelde e iconoclasta transcurrida en México donde, junto a sus compañeros los infrarrealistas, emprendió la búsqueda utópica de nuevas maneras de hacer poesía y con ello transformarse y transformar la realidad latinoamericana.

Existe una marcada intratextualidad en toda la obra de Bolaño, no sólo entre sus obras narrativas, sino entre éstas y sus poemas; ${ }^{1}$ lo que se puede constatar, comparando su novela más conocida Los detectives salvajes con el poemario Los perros románticos. La analogía entre ambas obras es tal, que el escritor argentino Rodrigo Fresán ha sugerido "intercambiar los títulos por Los perros salvajes y Los detectives románticos" (Huerga 2), pues el infrarrealismo confluye en las dos obras, algunos personajes que vagabundean en ellas son los mismos -en especial Bolaño y Mario Santiago, el Belano y Lima ficcionales

${ }^{1}$ Uno de los fundamentos del arte literario de Bolaño es la intratextualidad. Se considera ésta como la relación de un texto con otro u otros del mismo autor o de distintos autores, a los que recuerda por medio de citas, ecos, imitación, parodia, pastiche y transformaciones. Cuando el proceso intertextual opera sobre textos del mismo autor suele conceptuarse como intratextualidad o inter/intratextualidad. 
de Los detectives salvajes- e igual pasa con algunos espacios en que se sitúan los acontecimientos, como el México caótico y romántico de los años setenta, del que se destacan la metrópoli y el norte del país, además de una serie de poemas centrados en los detectives.

$\mathrm{El}$ hecho de que el infrarrealismo converja tanto en Los detectives salvajes -embozado de realvisceralismo- como en Los perros románticos -donde se evoca sin denominarlo-, no significa que la segunda sea una obra infrarrealista ni mucho menos; sin embargo, algunos de los poemas que la estructuran de muchas maneras se nutren en ese movimiento de juventud de Bolaño, pero ahora su poesía aparece perfeccionada a través del tiempo, desbordando el pasado anhelo de ruptura y subversión.

Sin embargo, las claves de la obra y personalidad del escritor chileno están ya dadas en sus primeros poemas, por lo que se hace necesario un estudio riguroso de la poesía infrarrealista, si bien resulta difícil reunir los textos que la conforman en su totalidad, pues éstos, en la mayor parte de los casos, se encuentran dispersos en ediciones y revistas marginales o cuasimarginales, por lo que la tarea inicial que tendría que emprender el investigador que acoja este reto sería la de convertirse en detective en búsqueda de los textos infrarrealistas.

\section{La obra poética de Bolaño}

De la etapa infrarrealista de Roberto Bolaño se conservan los poemas incluidos en la antología-revista Pájaro de calor. Ocho poetas infrarrealistas impreso en 1976 por Ediciones Asunción Sanchís; Reinventar el amor, su primera publicación individual editada por Juan Pascoe en el Taller Martín Pescador, también en 1976; y el manifiesto infrarrealista Déjenlo todo nuevamente, firmado por los miembros del

${ }^{2}$ Los ocho jóvenes poetas que firman este texto son: José Vicente Anaya, Mara Larrosa, Cuauhtémoc Méndez, Bruno Montané, Rubén Medina, José Peguero, Mario Santiago y Roberto Bolaño. 
grupo en 1976 y publicado en 1977 en la revista Correspondencia infra. Revista Menstrual del Movimiento Infarrealista. ${ }^{3}$

En 1979, instalado ya el escritor chileno en España, se publica en México por la editorial Extemporáneos la antología Muchachos desnudos bajo el arcoiris de fuego (11 poetas jóvenes latinoamericanos), que contiene piezas poéticas de tres infrarrealistas: Mario Santiago, Bruno Montané y el propio Bolaño. Asimismo, poemas de éste, Alberto Gallero y Bruno Montané se encuentran en la antología Regreso a la Antártida, Gerona, 1983.

La historia personal poética del autor, desligada ya de los infrarrealistas, se inicia en 1993 con Fragmentos de la Universidad Desconocida; al que siguen el cuaderno titulado El último salvaje, México, 1995; Los perros románticos del mismo año; Tres, en el año 2000 y La Universidad Desconocida en 2007, libro póstumo en que no sólo incorpora varios inéditos, sino que reordena los materiales anteriores.

\section{Vida y creación inextricablemente unidas}

Con Los perros románticos Bolaño obtiene el premio literario Ciudad de Irún 1994 otorgado por la Fundación Kutxa y creado para estimular la creatividad literaria y contribuir a su difusión social. El libro contiene textos escritos entre 1980 y 1998 según el subtítulo lo anuncia; la primera edición data de 1995 y tendrá tres reediciones posteriores en 2000, 2006 y 2010, que muestran variantes sustanciales con respecto a la primera, pues se suprimen algunos poemas y se introducen otros con el fin de lograr mayor coherencia y unidad en su estructura interna.

${ }^{3}$ Andrea Cobas señala, aparte de este manifiesto, la existencia de otros dos: "Por un arte de la vitalidad sin límites" (1975), de José Vicente Anaya y "Manifiesto infrarrealista" (1975), de Mario Santiago Papasquiaro. Del primero se publicó sólo una versión en inglés en Contracultural, San Francisco, Estados Unidos; el segundo permaneció inédito hasta 2006 (13). 
En general, en los poemas que integran este poemario -como en la totalidad de la obra bolañiana- hay un predominio del registro autobiográfico, al configurarse en ellos diversos retazos o fragmentos de vida relacionados con la permanencia del poeta en México, ciudad a la que llegó con sus padres cuando era un adolescente. No realizó estudios universitarios, fue en realidad un autodidacta, formado en la lectura constante y profunda que siempre alternó con la escritura, aunque él confiesa en uno de sus libros: "Soy mucho más feliz leyendo que escribiendo" (Entre paréntesis 20).

Bolaño vivió en la Ciudad de México de 1968 a 1977. Al llegar le tocó en suerte percibir el convulsionado clima social producido por la rebelión estudiantil del 68 y la fatídica matanza ocurrida en el mismo año en la Plaza de las Tres Culturas en Tlatelolco. Este hecho imprimió tanto en él, como en muchos miembros de su generación, una actitud de inconformidad ante un sistema represor e injusto, contradictoriamente surgido del movimiento revolucionario de 1910. Dos años después, hacia 1970, el joven chileno se inició en la literatura y militó en el trotskismo.

De Bolaño se ha dicho con suma ironía, aludiendo a Los detectives salvajes, que es un escritor chileno que escribió en España una de las mejores novelas mexicanas contemporáneas, ${ }^{4}$ y que es un chileno sólo a medias porque ha pasado la mayor parte de su vida en México y España. Al respecto de los sarcasmos y confusiones que solían hacerse sobre su nacionalidad declara en el "Discurso de Caracas":

pues a mí lo mismo me da que digan que soy chileno, aunque algunos colegas chilenos prefieran verme como mexicano, o que digan que soy mexicano, aunque algunos colegas mexicanos prefieran considerarme español, o, ya de plano, desaparecido en combate, e incluso lo mismo me da que me consideren español, aunque algunos colegas españoles pongan el grito en el cielo y a partir de ahora digan que soy venezolano, nacido

${ }^{4}$ Jorge Herralde atribuye la expresión al ensayista chileno Juan Antonio Masoliver Ródenas en "Para Roberto Bolaño" (2). 
en Caracas o Bogotá, cosa que tampoco me disgusta, más bien todo lo contrario. Lo cierto es que soy chileno y también soy muchas otras cosas. (Entre paréntesis 36)

Su amor a Chile y sus ideales revolucionarios hicieron que en 1973 regresara a su país natal con el fin de participar en el proyecto socialista de Allende. Tras un largo viaje por tierra llegó a Santiago un mes antes del golpe militar. Participó en la resistencia y fue encarcelado durante un breve periodo; pero tuvo la suerte de ser liberado por dos de los policías vigilantes que lo ayudaron al reconocerlo como uno de sus antiguos compañeros del liceo. ${ }^{5}$

\section{Su etapa infrarrealista}

Bolaño, después de esta aventura, regresó a México donde, a finales de 1975 y principios de 1976, fundó junto con Mario Santiago Papasquiaro $^{6}$ el grupo de poetas infrarrealistas, un movimiento de carácter marginal y contestario integrado por jóvenes rebeldes e inconformes con el status quo, que presenta puntos de contacto con el estridentismo, los beatniks y Hora Zero del Perú. Los infrarrealistas pretendían fundar un movimiento de vanguardia en plena posvanguardia con el fin de revolucionar el campo literario mexicano y el latinoamericano, oponiéndose belicosamente a los poetas consagrados y a sus seguidores. Pugnaban por imponer un nuevo modo de hacer poesía, fracturando los moldes poéticos establecidos y haciendo del poema un artefacto dirigido a dinamitar la cultura oficial.

${ }^{5}$ En cuanto al número de sus salvadores, hay diversas versiones; yo me baso en lo relatado por Bolaño en "Carnet de baile" incluido en Putas asesinas y "Detectives", en Llamadas telefónicas, donde Arturo Belano (álter ego del escritor) cuenta en el primero la "acción" que le fue encomendada el día del golpe pinochetista y su posterior detención y liberación (216); y en el segundo, la charla que sostienen sus dos excondiscípulos, en la que recuerdan el tiempo en que Belano estuvo detenido.

${ }^{6}$ El verdadero nombre de este poeta, que nació y murió en la Ciudad de México, 1953-1998, fue el de José Alfredo Zendejas. 
Roberto Bolaño y Mario Santiago se constituyeron en pilares del movimiento, al cual se integraron, entre los más asiduos, los hermanos Cuauhtémoc y Ramón Méndez Estrada, Bruno Montané, Juan Esteban Harrington, Óscar Altamirano, José Peguero, Guadalupe Ochoa, José Vicente Anaya, Edgar Altamirano, José Rosas Ribeyro, Elmer Santana y Mara Larrosa. La energía desbordante de sus fundadores contagió con violencia a sus seguidores e influyó de manera determinante en el destino de los infras. Hacia 1977 del grupo original ya no quedaba mucho: Bolaño emigró a Francia, África y finalmente a España, donde se instalaría hasta su muerte; Santiago anduvo por Israel y Europa, para morir finalmente atropellado por un camión en el D. F., en 1998.

\section{Déjenlo todo, nuevamente}

Las tentativas iniciales del grupo se condensan en el ya citado primer manifiesto "Déjenlo todo, nuevamente", que según Luis Bagué: "Ofrece una visión bastante heterogénea, que oscila entre el empuje revolucionario, el malditismo romántico y la ingenuidad juvenil” (489). De hecho, la mayoría de los infra se adhirió sólo románticamente a la idea de revolución sin respaldarla mediante la participación en movimientos insurgentes. El binomio "poesía y revolución” cifró sus aspiraciones de encontrar el único camino, aunque utópico, para construir la nueva poesía y la nueva sociedad, mediante la subversión de lo cotidiano, de modo que el poeta se convirtiera en ojo o testigo que pudiera dar cuenta de las realidades más lacerantes del México de los setenta, buscando en las calles una nueva sensibilidad poética. Así, en el manifiesto se exhorta al:

Desplazamiento del poema a través de las estaciones de los motines: la poesía produciendo poetas produciendo poemas produciendo poesía. No un callejón eléctrico / el poeta con los brazos separados del cuerpo / el poema desplazándose lentamente de su Visión a su Revolución. El callejón es un punto múltiple. "Vamos a inventar para descubrir su contradicción, sus formas invisibles de negarse, hasta aclararlo". 
Desplazamiento del acto de escribir por zonas nada propicias para el acto de escribir. (5)

Sin embargo, se percibe desde un principio una suerte de desesperanza junto a los ímpetus revolucionarios:

-Que la amnesia nunca nos bese en la boca. Que nunca nos bese.

-Soñábamos con utopías y nos despertamos gritando. (9)

Con el tiempo se han mitificado pasajes de la existencia de los infra, es el caso de la famosa rebelión encabezada por Mario Santiago contra Juan Bañuelos, director del taller literario de la UNAM al que asistían algunos de ellos y que algunos críticos consideran el punto de partida del movimiento; del asalto a una de las reuniones culturales de Octavio Paz a quien consideraban representante fundamental del establishment literario mexicano; de sus consuetudinarias reuniones en el café La Habana que aparece como el café Quito en Los detectives salvajes y de las interminables caminatas que algunos de sus integrantes -Bolaño y Santiago particularmente- emprendían por la Ciudad de México.

La actitud arrogante y las acciones provocadoras de los infrarrealistas fueron motivo de múltiples calumnias y rechazos, se les vio como jóvenes terroríficos, lumpenproletarios, rebeldes, desesperados, marginales, melenudos, etcétera: "Tal vez esto sea lo que el espejo nos devuelve -acierto más, acierto menos- de nuestro trabajo: jóvenes ridículos y mal vestidos, poetas mendicantes, viejos detectives latinoamericanos que se pierden en una investigación vana y peligrosa", expresa Bolaño en el prólogo de la edición de Los perros románticos de la Fundación Kutxa (7).

¿Cómo explicar el desdén hacia el infrarrealismo? A esta pregunta, Bolaño responde al periodista Fernando Villagrán, en una entrevista para Arcoiris de Chile:

Básicamente lo que molestaba mucho al status de la literatura mexicana, es que no estábamos con ninguna mafia, con ningún grupo de poder. En la literatura mexicana de aquella época, y 
supongo que en esta también, siempre ha habido parcelas y clanes [...] y nosotros no estábamos con ninguno. No estábamos con la izquierda, una izquierda stalinista, dogmática, dirigista, juna izquierda espantosa, vaya! Ni con la derecha exquisita que de exquisita prácticamente no tenía nada, una exquisitez llena de polvo. Ni con los vanguardistas, que lo único que les interesaba era ganar dinero y además hacían una vanguardia periclitada hacía mucho tiempo atrás. Nosotros lo que hacíamos era molestar. Recuerdo que alguien, en su único minuto de gran inspiración, llegó a publicar un texto donde decía “Que Bolaño se vaya a Santiago y que Santiago también”, porque no nos aguantaban en México de verdad. Era un odio total, no nos querían para nada. (http://es.arcoiris. TV)

El grupo infrarrealista permaneció y permanece olvidado para la cultura oficial y su existencia hubiera pasado inadvertida si Bolaño no hubiera contado la historia de este puñado de valientes y estrafalarios jóvenes vencidos por la realidad en Los detectives salvajes, novela que lo lanzó a la fama y con la que obtuvo los premios Herralde en 1998 y Rómulo Gallegos en 1999; al respecto comenta el autor:

En este sentido la novela intenta reflejar una cierta derrota generacional y también la felicidad de una generación, felicidad que en ocasiones fue el valor y los límites del valor. [...] Creo que mi novela tiene casi tantas lecturas como voces hay en ella. Se puede leer como una agonía. También se puede leer como un juego. (Entre paréntesis 327)

\section{Los perros románticos}

El poema inicial de Los perros románticos, que lleva el mismo título del libro, se impregna de recursos biográficos y testimoniales disimulados por la voz del sujeto lírico que trae a la memoria sus recuerdos de los años juveniles y el fracaso de su aventura revolucionaria en Chile, tras la que regresa a México como perro apaleado, con la cola 
entre las patas y las cicatrices de la derrota, pero habiendo ganado un gran sueño:

En aquel tiempo yo tenía veinte años

y estaba loco.

Había perdido un país

pero había ganado un sueño. (13)

Las visiones oníricas, elemento recurrente en la poesía de Bolaño, y los impulsos del inconsciente circulan en torno al yo y entran al texto, en el que en un sueño originalmente inocuo se instala otro sueño cargado de erotismo, que conduce al amor desbocado y finalmente a la pesadilla:

Y la pesadilla me decía: crecerás.

Dejarás atrás las imágenes del dolor y del laberinto y olvidarás.

Pero en aquel tiempo crecer hubiera sido un crimen. (13)

El poeta presiente su futuro glorioso y distinto al de sus compañeros, desde el cual recuerda que en aquel momento vivía intensamente su presente, tomando una opción radical por los perros románticos.

Estoy aquí, dije, con los perros románticos

y aquí me voy a quedar. $(13)^{7}$

Los perros románticos es una metáfora de tipo nominal con la que el sujeto lírico representa a los poetas infrarrealistas, como él perros callejeros, apaleados, errabundos que vagan por las calles de la Ciudad de México; con vocación de perros románticos porque como poetas tienen algo de romántico, de bohemio, de soñador, de idealista, de utópico, tras el gran sueño de unir poesía con vida y revolución.

${ }^{7}$ De la edición de 2010: Roberto Bolaño. Los perros románticos. Poemas 19801998. Acantilado Bolsillo. Barcelona, proceden los fragmentos de los poemas citados en el presente trabajo. 
El tema del poema liminar reaparece en el titulado "Sucio, mal vestido", en que destaca el tono de confesión: al regresar a México el poeta encuentra una salida para su corazón herido al unirse a los perros románticos, lo que imprime un sentido a su vida, pese a las dificultades del camino:

En el camino de los perros mi alma encontró a mi corazón. Destrozado pero vivo, sucio, mal vestido y lleno de amor.

En el camino de los perros, allí donde no quiere ir nadie.

Un camino que sólo recorren los poetas

cuando ya no les queda nada por hacer.

¡Pero yo tenía tantas cosas que hacer todavía! [...]

Un chileno educado en México lo puede soportar todo, pensaba, pero no era verdad. (32)

Continuamente el poeta refrenda su pertenencia a los perros, el estar en su camino, el participar de su errancia y de su búsqueda, pero los recuerda desde la nueva visión de su desarrollo posterior, en el que avanza en solitario y en el que los perros pasan a formar parte del mundo de sus sueños, ahora mediante la metáfora "detectives helados", igual a congelados, fracasados:

Soñé con detectives helados en el gran refrigerador de Los Ángeles

en el gran refrigerador de México D. F. (33)

Atrapado en la memoria el poeta evoca su aventura infrarrealista, una historia hermosa pero también trágica, y de ella a diversos personajes con sus nombres propios, especialmente a Mario Santiago, el amigo más querido en su vida, con el que constituyó la pareja más temible de la época: los dos viscerales, rabiosos, ególatras, pero, ante todo, amigos. Mario aparece en varios poemas bolañianos, constituyéndose en una especie de obsesión; en la vida real, le perdía la pista, pero nunca dejaba de preocuparse por él. Uno de los poemas de $L a$ Universidad Desconocida se titula precisamente "Mario Santiago": 


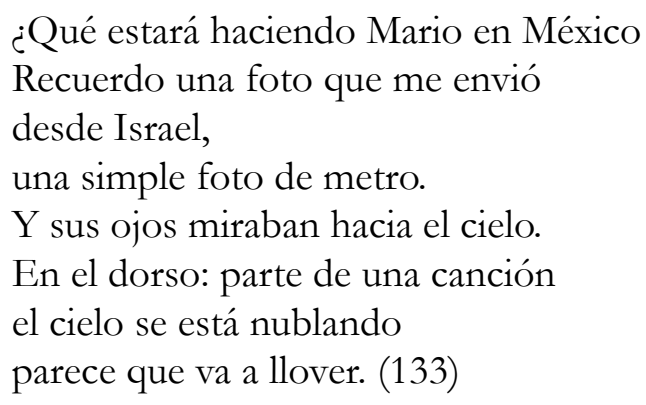

Igual ocupan el centro de otros poemas algunos amigos comunes a los infras entre ellos Darío Galicia (el Ernesto San Epifanio de Los detectives salvajes) y Orlando Guillén; así como mujeres a las que Bolaño amó como Edna Liebermann; mitifica así la vida de sus compañeros y de él mismo, que pasan a formar parte del contenido de su poesía.

En "La visita al convaleciente" Mario Santiago y el sujeto lírico visitan a Darío Galicia, quien se recupera de una intervención quirúrgica; algunos datos proporcionados en el texto coinciden con hechos sucedidos en 1976, año en que a Galicia -trágico y joven poeta, pionero en el intento de fundar un partido comunista homosexual y la primera comuna proletaria homosexual- le abrieron el cráneo para extraerle dos aneurismas, quedando impedido para volver a escribir. La anáfora enfatiza esta fecha a lo largo del poema, para destacar, aparte de la tragedia del amigo, la derrota de la revolución y los adioses que un año después se producirían con la partida de Bolaño a Europa y la dispersión de los infras:

Es 1976 y la Revolución ha sido derrotada pero aún no lo sabemos [...]

Es el año 1976 y a Darío Galicia le han trepanado el cerebro.

Está vivo, la Revolución ha sido derrotada, el día es bonito $[\ldots]$

Pero es el año 1976 y la cabeza de Darío Galicia tiene las marcas indelebles de la trepanación.

Es el año previo de los adioses 
que avanza como un enorme pájaro drogado por los callejones sin salida de una vecindad detenida en el tiempo. (40-44)

Predomina en el poema un tono de tristeza y de congoja, pero las emociones aparecen contenidas; mientras conversan, los personajes continuamente escuchan que alguien llora:

Estuve a punto de morir, dice después de pensarlo mucho. Por un momento creemos que va a llorar.

Pero no es él el que llora.

Tampoco es Mario ni yo.

Sin embargo alguien llora mientras atardece con una lentitud inaudita. (42)

Lo que contrasta con fragmentos cargados de profunda ironía:

Es 1976 y es México y los amigos dicen que Darío lo ha olvidado todo, incluso su propia homosexualidad.

Y el padre de Darío dice que no hay mal que por bien no venga. (41)

En los poemas que integran el libro, Bolaño despliega una galería de experiencias frustradas que se propone redimir por medio de la voluntad poética:

aquello innombrable, parte del sueño, que muchos años después

llamaremos con nombres varios que significan derrota.

La derrota de la poesía verdadera, la que nosotros escribimos con sangre.

Y semen y sudor, dice Darío.

Y lágrimas, dice Mario.

Aunque ninguno de los tres está llorando. (44) 


\section{Poetas, perros, detectives}

En otros poemas los perros o poetas son artilleros, quizá por el carácter dinamitador de su poesía o bien se personifican en la figura del detective, de modo que se establece una equivalencia entre las figuras de poetas y detectives, y de éstos con los perros.

El personaje del detective puede ser una figura representativa de la concepción estética de Bolaño, pues aparece de manera obsesiva en sus composiciones tanto poéticas como narrativas. ${ }^{8}$ Los detectives, tanto en la novela como en los poemas, buscan personas perdidas, amores, esencias, territorios, pero sobre todo hurgan en lo profundo de la realidad, en las vísceras de la realidad: "-la infrarrealidad justamente- de quienes lo han arriesgado todo, y tal vez lo han perdido todo: los desesperados de y por la literatura" (Bolognese 133).

Soñé con detectives perdidos en la ciudad oscura.

Oí sus gemidos, sus náuseas, la delicadeza

De sus fugas. [...]

Absolutamente desesperados. (34)

Los detectives deambulan por una cartografía simbólica, posible de trasladar a un plano concreto: "el gran refrigerador de México D. F.", "la ciudad oscura", el "Teatro de la Juventud" y los “cafés y parques frecuentados en la adolescencia". No obstante, la pesquisa detectivesca está condenada al fracaso de antemano:

Los detectives que observan

Sus manos abiertas,

${ }^{8}$ El oficio de detective es equiparado por Bolaño con el de escritor en una entrevista que le hizo Mónica Maristain para Playboy. A la pregunta: "¿Qué le hubiera gustado ser en lugar de escritor?”, él contesta: "Me hubiera gustado ser detective de homicidios mucho más que ser escritor. De eso estoy absolutamente seguro. Un tira de homicidios, alguien que puede volver solo, de noche, a la escena del crimen, y no asustarse de los fantasmas. Tal vez entonces sí me hubiera vuelto loco, pero eso, siendo policía, se soluciona con un tiro en la boca" (Entre paréntesis 343). 
El destino manchado con la propia sangre.

Y tú no puedes ni siquiera recordar

En dónde estuvo la herida,

Los rostros que una vez amaste,

La mujer que te salvó la vida. (35)

En la pieza que cierra esta serie, "Los detectives helados", éstos sueñan en casos difíciles de crímenes que encarnan o se encarnan en el Espanto como signo de nuestro tiempo, en cuanto condensan el mal como enfermedad extendida en la sociedad, y se reflejan en el espejo convexo de Los Arnolfini, semejante a la forma en que el cuadro de Van Eyck, a través de la imagen angular del espejo convexo, nos procura la visión que completa la escena representada, cerrando el espacio tan real como ficticio del cuadro. ${ }^{9}$

Soñé con detectives perdidos

en el espejo convexo de los Arnolfini:

nuestra época, nuestras perspectivas,

nuestros modelos del Espanto. (36)

A lo largo de los versos del poemario que se ha venido analizando, Bolaño produce su poesía en un constante proceso de aprendizaje estético y vital al que se entrega incondicionalmente, asumiéndola como una experiencia nueva del lenguaje, lenguaje vivo ad hoc para el tipo de poesía narrativa que cultiva; huye de la nomenclatura de los géneros, fusionando en forma natural la narrativa y la lírica, contra el criterio canónico que define la poesía como género subjetivo no apto para abordar la ficción, o plantear un referente; así, traza una línea divisoria en relación con la poesía considerada como exaltación de una idealidad superior e inefable, ubicándose en un espacio crítico y subvertidor.

${ }^{9}$ En el cuadro El matrimonio Arnolfini, 1434, National Gallery, Londres, los esposos están frente al pintor, pero en la realidad del espejo parecen estar despidiendo a las figuras que los observan desde la puerta, en el mismo lugar que ocupamos nosotros al mirar el cuadro. 
Tanto los temas como las experiencias y el lenguaje empleado provienen de la cotidianidad, de modo que algunos poemas resultan de aparente sencillez; pero en la mayoría de ellos las realidades tratadas se mezclan con alucinaciones inducidas por las drogas y las ensoñaciones y son transferidas al mundo de lo insólito, deformándolas; dicha mezcla proporciona al texto o a ciertos pasajes del mismo una deliberada oscuridad que provoca en el lector tensión, inquietud, sorpresa y desconcierto.

Por otra parte, aunque el poeta trata de huir del hermetismo y de la intelectualización, su poesía resulta bastante compleja y no escapa a ciertas características generales de la poesía moderna, sobre todo a la disonancia, según la explica Hugo Friedrich:

Podemos dar a esta coincidencia del hechizo con la ininteligibilidad el nombre de disonancia, pues de ella resulta una tensión que se acerca mucho más a la inquietud que al reposo $[\ldots]$. Esta tensión disonante del poema moderno se manifiesta también en otros sentidos: [...] ciertas formas muy sencillas de expresión concurren con la complicación de lo expresado, la rotundidad del lenguaje con la oscuridad del contenido, la precisión con la absurdidad. (14-15)

\section{Autorretratos}

Existen en la poesía bolañiana diversos autorretratos poéticos, con distinto grado de semejanza entre el autor y el hablante poético, cultivados como un medio de enfrentar la identidad; uno de los más conocidos es el "Autorretrato a los veinte años", donde el poeta no sólo persigue la autocontemplación estética, sino que amplía su campo de representación al de un grupo generacional en un determinado momento histórico, aquel en que deciden la opción por las armas:

Me dejé ir, lo tomé en marcha y no supe nunca hacia dónde hubiera podido llevarme. Iba lleno de miedo, $[\ldots]$ pese al miedo, me dejé ir, puse mi mejilla 
junto a la mejilla de la muerte.

Y me fue imposible cerrar los ojos y no ver aquel espectáculo extraño, lento y extraño, aunque empotrado en una realidad velocísima:

miles de muchachos como yo, lampiños o barbudos, pero latinoamericanos todos, juntando sus mejillas con la muerte. (14)

El poeta se identifica de esta manera con los miles de jóvenes latinoamericanos que en los setenta asumieron el riesgo entre vida y muerte, participando abiertamente en las luchas revolucionarias latinoamericanas, y hace del poema un homenaje a esta generación de la que consideraba formar parte:

en gran medida todo lo que he escrito es una carta de amor o despedida a mi propia generación, los que nacimos en la década del cincuenta y los que escogimos en un momento dado el ejercicio de la milicia, en este caso sería más correcto decir la militancia, y entregamos lo poco que teníamos, lo mucho que teníamos, que era nuestra juventud, a una causa que creíamos la más generosa de las causas del mundo y que en cierta forma lo era, pero que en la realidad no lo era. [...] porque fuimos estúpidos y generosos como son los jóvenes, que todo lo entregan y no piden nada en cambio, y ahora de esos jóvenes ya no queda nada, los que no murieron en Bolivia, murieron en Argentina o en Perú, y los que sobrevivieron se fueron a morir a Chile o a México, y a los que no mataron allí los mataron después en Nicaragua, en Colombia, en el Salvador. Toda Latinoamérica está sembrada con los huesos de estos jóvenes olvidados. (Entre paréntesis 212)

La brevedad caracteriza al autorretrato trazado en el poema titulado "En la sala de lecturas del infierno", aquí el sujeto lírico se representa como el lector voraz que fue, a los veintiséis años, errabundo por Europa y con miedo a lo por venir: 
En la sala de lecturas del Infierno En el club de aficionados a la ciencia ficción

En los patios escarchados En los dormitorios de tránsito

En los caminos de hielo Cuando ya todo parece más claro

$Y$ cada instante es mejor y menos importante

Con un cigarrillo en la boca y con miedo A veces los ojos verdes Y 26 años Un servidor. (16)

El poeta hace alusión a sus múltiples lecturas: por un lado, el género B que comprende "como anota la crítica Patricia Espinosa [...], géneros bastardos, ya sea cine porno, ciencia ficción, peplum o relato policial" (Ruiz 2); por otro, los clásicos griegos, Rimbaud y los simbolistas, Borges, Whitman, los beatniks, los poetas y juglares medievales, Nicanor Parra, Ernesto Cardenal y un largo etcétera. Resulta así un lector ávido que no obstante conserva y asume una personalidad y un mundo poético propios.

Otros poemas podrían considerarse como autorrretratos de la cotidianidad, porque aportan diversos datos para reconstruir sus experiencias vitales. En dos de ellos, incluidos en La Universidad Desconocida, se pinta "el poeta de niño", según su propia expresión. En el primero emplea la autonominación como estrategia discursiva, pues se presenta con su nombre y fecha de nacimiento, homologándose así el hablante lírico con el autor, además de mencionar veladamente su travesía urbana en la Ciudad de México

Nací en Chile en 1953 y viví en varias y

distintas casas

Después llegaron los amigos pintados por Posadas

y la región más transparente del mundo. (430)

El segundo de los autorretratos oscila entre la evocación idílica de su infancia en Chile, los juegos con los amigos teñidos de un peligro vago e incierto, y la mirada o despedida desde un presente en el que hasta los nombres de las amistades infantiles se olvidan o confunden: 
Valientes y audaces, como para no morir nunca, mi pandilla siguió peleando

mientras los autobuses mataban a los niños solitarios.

Así, sin darnos cuenta,

lo fuimos perdiendo todo. (431)

\section{Nostalgia de México}

México es tema central de la poesía bolañiana, del que configura dos espacios antitéticos, el Norte y la capital. Por un lado, celebra la naturaleza hostil del norte mexicano en los poemas titulados "El gusano" y "El burro"; por otro, la Ciudad de México es recreada en múltiples poemas como parte de la mitología personal del autor, me referiré a "Atole" de Los perros románticos y a los dos poemas titulados "Un final feliz", incluidos en La Universidad Desconocida.

La relación intratextual de que se hablaba inicialmente se acentúa entre un poema de Los perros románticos y uno de los cuentos de Llamadas telefónicas, ambos con igual título, "El gusano". Sólo que en el relato el narrador es un adolescente con algunos rasgos semejantes al Bolaño biográfico joven: se va de pinta, roba libros, gusta de las funciones matinales de cine y lee mucho y, en el poema, el sujeto lírico transmite la visión onírica de un sujeto que vaga por el norte de México, muy parecido a "el gusano" del relato.

En el relato, el gusano vagabundea por los pliegues del centro de la ciudad; precisamente el narrador conoce a este sujeto en sus correrías por la Alameda:

Parecia un gusano blanco, con su sombrero de paja y un Bali colgándole del labio inferior. Todas las mañanas lo veía sentado en un banco de la Alameda mientras yo me metía en la Librería de Cristal a hojear libros. Cuando levantaba la cabeza, a través de las paredes de la librería que en efecto eran de cristal, ahí estaba él, quieto entre los árboles, mirando al vacío [el énfasis es mío]. (71) 
El narrador y el gusano se hacen amigos, viven algunas aventuras juntos; el gusano tiene la obsesión de irse al Norte de donde procede, le regala al muchacho una navaja con mango de hueso en el que se podía leer la palabra "Caborca", regalo que encierra, desde luego, un misterio, y un buen día desaparece.

En el poema, "El gusano" es un tipo harapiento que vaga por los pueblos de la frontera y no se atreve a bajar al Distrito Federal:

Parecía un gusano blanco

con un Bali entre los labios

o un Delicados sin filtro.

Y viajaba de un lado a otro

de los sueños,

tal que un gusano de tierra, arrastrando su desesperación, comiéndosela. (21)

La visión de los atardeceres norteños, descritos en el poema, motiva que el yo lírico recuerde al padre de Lisa y a Mario Santiago, pero predominan los paisajes desolados y las imágenes visionarias, de modo que en el último segmento del texto el sujeto lírico acaba por identificarse con el gusano, trasladándose al ambiente del Café La Habana, en una pesadilla alucinante y enigmática:

Parecía un chileno de veintidós años entrando en el café La Habana

y observando a una muchacha rubia

sentada en el fondo,

en la Mente desalojada.

Parecían las caminatas a altas horas de la noche

de Mario Santiago

en la Mente desalojada.

En los espejos encantados

En el huracán del D. F.

Los dedos cortados renacían

con velocidad sorprendente. 
Dedos cortados,
quebrados,
esparcidos
en el aire del D. F. (23)

Bolaño, como ya se ha visto, jamás perdería de vista la unión espiritual con Santiago, lo consideraba su mejor amigo. ${ }^{10}$ En Los detectives salvajes, Belano y Lima emprenden la búsqueda de Cesárea Tinajero -fundadora del primer infrarrealismo- en el Impala de Quim Font por el desierto de Sonora; en "El burro", los dos personajes antes mencionados nuevamente emprenden un viaje imaginario en motocicleta por esos lugares, "persiguiendo un sueño innombrable" (76). Huyen de la ciudad megalópolis para encontrarse con la modernidad "otra":

A veces sueño que Mario Santiago

Viene a buscarme con su moto negra [...]

Cómo negarme a montar la veloz moto negra

Del norte y salir rajados por aquellos caminos

Que antaño recorrieron los santos de México,

Los poetas mendicantes de México,

Las sanguijuelas taciturnas de Tepito

O la colonia Guerrero, todos en la misma senda,

Donde se confunden y mezclan los tiempos:

verbales y físicos, el ayer y la afasia. (76)

La recurrencia del sueño se manifiesta a través de la anáfora que abre la mayor parte de las estrofas irregulares: A veces sueño..., Y a veces sueño..., Y a veces creo... etcétera. El sueño se repite con más o menos variantes: en una de sus manifestaciones, Mario se dilu-

${ }^{10}$ Así lo confiesa en la famosa entrevista concedida a Playboy: "PLAYBOY: ¿Quiénes son sus amigos entrañables? BOLAÑO: Mi mejor amigo fue el poeta Mario Santiago, que murió en 1998. Actualmente tres de mis mejores amigos son Ignacio Echevarría, Rodrigo Fresán y ZA. G. Porta” (Entre paréntesis 332). 
ye en "un poeta sin rostro, / Una cabeza sin ojos, ni boca, ni nariz, / Sólo piel y voluntad [...] /"; en otra, la moto se semeja a un burro en el que el yo y Mario, del que no queda más que su cabeza, se desplazan por los miserables caminos del Norte, "El único teatro concebible para nuestra poesía":

\section{y nuestra moto entonces}

Es del color de la noche. Nuestra moto

Es un burro negro que viaja sin prisa

Por las tierras de la Curiosidad. Un burro negro

Que se desplaza por la humanidad y la geometría

De estos pobres paisajes desolados.

Y la risa de Mario o de la cabeza

Saluda a los fantasmas de nuestra juventud,

El sueño innombrable e inútil

De la valentía. (77)

De cierta manera, el poema proporciona una imagen delirante de los que ya no están y que el sueño recupera, especialmente a Mario y al mismo poeta en su juventud. Todo el poema se desarrolla en un ambiente onírico. El sueño significa la valentía de los dos jóvenes y de su poesía, la moto alude a la juventud perdida y recuperada en el sueño y en la palabra poética; la moto en medio del desierto potencia la complejidad del poeta héroe, de modo que la heroicidad adquiere un sentido colectivo que se manifiesta a través del empleo de formas pronominales posesivas en plural: nuestra poesía, nuestra moto, nosotros mismos, nuestra esperanza, nuestro valor.

El sueño también significa la despedida del amigo querido: "Y acaso son los gestos de valor los que/nos dicen adiós, sin resentimiento ni amargura,/En paz con su gratuidad absoluta y con nosotros mismos" (78). La aventura implica presencia-ausencia, vidamuerte, sueño-vigilia, lucidez-alucinación. El lector, propenso a la tranquilidad del canon, como partícipe de dicho proceso se torna igualmente alucinado, condición necesaria para deambular por la poesía bolañiana. 
En una línea diferente la poesía de Bolaño se enmarca en la ciudad como hábitat natural del hombre moderno. La ciudad: un espacio brumoso constituido por calles, barrios y lugares cotidianos: la Guerrero, la colonia Tepeyac, Bucareli, la Alameda, la Librería de Cristal, el Gimnasio Moctezuma, rememorados a través de los sueños: "que lo trasladaban a ese país mágico/que él y nadie más llamaba México, D. F." ("Devoción de Roberto Bolaño", La Universidad desconocida 397).

Bolaño, pues, se fue de México para no volver, pero retorna a él con insistencia a través de los sueños y los recuerdos contenidos en su escritura. En "Atole", poema incluido en Los perros románticos, el poeta transita por los pasillos de una nueva universidad, que se desarrolla en la secuencia metafórica urbe/infierno: "una nueva universidad/llamada infierno o algo que podía ser/una especie de infierno pedagógico" (74). ${ }^{11}$

En los murales de esa universidad, el poeta ve a Mario Santiago y Orlando Guillén, ${ }^{12}$ los poetas perdidos de México, a quienes representa, en forma por demás absurda e irónica, viviendo adentro de un mural y "tomando atole con el dedo", metáfora cotidiana que puede significar "tomadura de pelo", "haciéndose o dejándose hacer tontos", o metidos en sueños irrealizables:

Amigos míos era el día en que se estrenaba

Los Poetas Perdidos de México

así que ya se lo pueden imaginar.

${ }^{11}$ La metáfora hace pensar en la concepción bolañista de la universidad desconocida: "Creo que en la formación de todo escritor -afirmó Bolaño- hay una universidad desconocida que guía sus pasos, la cual evidentemente, no tiene sede fija, es una universidad móvil, pero común a todos" (La Universidad Desconocida, s.n.p.).

${ }^{12} \mathrm{El}$ poeta Orlando Guillén (1945) fue muy cercano a los infrarrealistas y participó en algunas de sus publicaciones, sin militar en el movimiento. Fue miembro del taller literario de Juan Bañuelos. Ha mantenido una oposición crítica y de confrontación con el status quo. Es autor, entre otras obras, de Versario pirata, Rey de bastos y El costillar de Caín. 
Y Mario y Orlando reían, pero como en cámara lenta como si en el mural en el que vivían no existiera la prisa o la velocidad. (74)

De la ironía y el absurdo el poeta salta a los recuerdos. Mediante la interrogación se dirige a un interlocutor que puede ser él mismo: ¿los recuerdas? Sí los recuerdo, pero vivos, sonrientes: "Cuando aún no vivían dentro del mural laberíntico/apareciendo y desapareciendo como la poesía verdadera/esa que ahora visitan los turistas" (75).

La imagen de los amigos, borrachos y drogados, se diluye en el "esplendor geométrico/que es el México que les pertenece" (75). Entra en juego la nostalgia, al traer el poeta a sus versos un pedazo de lo que vivió y dejó profunda huella en su ser:

El México de las soledades y los recuerdos el del metro nocturno y los cafés de chinos el del amanecer y el del atole". (75)

La nostalgia de México "aparece y desaparece en todos los poemas" de la última sección de La Universidad Desconocida y se intensifica particularmente en los dos titulados "Un final feliz". En el segundo de ellos, el poeta se sitúa a los veintiún años en casa de su padre: "Qué tiempos aquéllos, cuando vivía con mi padre y no veía la televisión” (437), dedicado a la lectura y traducción de poetas franceses, o en casa de su madre, observando melancólicamente las calles cercanas, registrando el paisaje, el movimiento y hasta los ruidos de los tranvías al pasar por la calle de Bucareli.

En el primero de estos poemas recuerda a sus compañeros de juventud:

\author{
Nosotros \\ Los de antes \\ Sin fotografías \\ De las aventuras \\ Pasadas \\ Sin Recuerdos \\ Humildes y dichosos
}


En México
En el atardecer
Sin mácula
De México. (429)

Los jóvenes y románticos poetas, entonces humildes y dichosos, errabundos en medio del camino, pronto se ven vencidos por la realidad. Ahora los perros románticos, con "los que estoy aquí y aquí me voy a quedar", como el sujeto lírico proclama en el poema liminar de Los perros románticos, pasan a formar parte de la película escenificada por Mario Santiago y Orlando Guillén, Los Poetas Perdidos de México; sin embargo, la marca de perro romántico la llevó Bolaño toda su vida.

Bolaño, comenta el crítico chileno Grinor Rojo,

es un escritor que se moviliza en dos tiempos. En uno de ellos, en el tiempo viejo, el que él deja atrás, se aloja la pasión revolucionaria, el fervor del cambio, la rebeldía y la audacia juveniles, y en el otro, el tiempo nuevo en que reside después del agotamiento de aquel desborde de vida y que es donde al fin de cuentas ejecuta su escritura, lo que se aloja es el mundo maduro pero también caído de la postrevolución. (Rojo 208)

Los perros románticos es ante todo una memoria, un recuento de vida que se ha congelado en un tiempo perpetuo, el único que podría hacer tolerable al poeta los demás procesos del futuro. Lo que nos dice en esencia, su significado profundo, es que la vida sólo puede sobrellevarse y sobrevivirse gracias a la perdurabilidad del sueño.

Aceptar la invitación que el poeta nos hace para leer sus poemas, es aceptar cruzarnos por sus sueños pesadillescos, por sus mundos delirantes, por sus ilusiones, angustias, terrores, búsquedas, amores; es también aceptar la ruptura de nuestros moldes lectoriales y cambiar de dirección única, de la búsqueda de un sentido único y divagar por los recovecos y callejones de una poesía donde el relato y la imagen poética son pares necesarios, enmarcados por las figuras de la transgresión: la irreverencia, el desparpajo, la ironía, el sarcasmo, el 
absurdo, pero igual por el sentimentalismo retenido, la nostalgia, la melancolía y la rabia por lo que pudo haber sido y no fue.

\section{Obras citadas}

Areco, Macarena. "Los detectives salvajes de Roberto Bolaño y el juicio de la vanguardia". Anales de la literatura chilena 8. (2007): 185-197. Bagué, Quílez Luis. "Retrato del artista como perro romántico: la poesía de Roberto Bolaño”. Lectura y signo 3. (2008): 487-508.

Bolaño, Roberto. "Déjenlo todo, nuevamente. Primer manifiesto infrarrealista". Correspondencia infra, revista menstrual del movimiento infrarrealista 1. (1977): 5-11.

- Reinventar el amor. México: Taller de Martín Pescador, 1976. y Jorge Boccanera. "La nueva poesía latinooamericana ¿Crisis o renacimiento?" Plural 68. (1977): 41-49.

- Putas asesinas. Barcelona: Anagrama, 2001.

- La Universidad Desconocida. Barcelona: Anagrama, 2007.

- Llamadas telefónicas. 6a. ed. Compactos Anagrama. Barcelona: Anagrama, 2007.

- Entre paréntesis. Ensayos, artículos y discursos (1998-2003). Ed. Ignacio Echevarría. Argumentos. Barcelona: Anagrama, 2004. Bolognese, Chiara. "Roberto Bolaño y sus comienzos literarios: El infrarrealismo entre realidad y ficción". Acta Literaria 39. (2009): 131-140.

Cobas Corral, Andrea. "La estupidez no es nuestro fuerte. Tres manifiestos del movimiento infrarrealista mexicano". Osamayor. Graduate Student Review 17. (2006): 11-29.

Friedrich, Hugo. Estructura de la lírica moderna. De Baudelaire hasta nuestros dias. Tr. Juan Petit. Biblioteca Breve. Barcelona: Seix Barral, 1959.

Herralde Jorge. "Para Roberto Bolaño". Roberto Bolaño. www.elortiba.org/bolano.html. Consultado 15/08/2011.

Huerga, Carlos. "La poesía de Roberto Bolaño". Deriva: revista de literatura y cine. http://.español.agonia.net/index.html. Consultado 02/09/2011. 
Pino, Mirian. "Enigma de (Poe)sía: "El burro" de Roberto Bolaño” y "Gas de los matrimonios" de Eduardo Espina". Literatura y Lingüística 19. (2008): 101-113.

Rojo, Grinor. "Bolaño y Chile". Anales de la literatura chilena 5. (2004): 201-211.

Ruiz, Felipe. "Bolaño y el país de los soles negros". Artes y letras, supl. cult. de El Mercurio. Santiago de Chile, 6 de noviembre de 2005. <http://www.letras.s5.com/rb220206.htm>. Consultado en $02 / 09 / 2011$. 